\title{
The Madness of Crowds: Gender, Race, and Identity by Douglas Murray
}

\section{(Bloomsbury Continuum, 2019), 2020 Paperback Edition with New Afterword by Author, 304 pp., ISBN 978-1472979575.}

\author{
Michael Laver ${ }^{1}$ \\ Published online: 9 April 2021 \\ (C) Springer Science+Business Media, LLC, part of Springer Nature 2021
}

It might seem a little late to be reviewing this book. It is already notorious. The current edition comes pre-loaded with snippets of fulsome praise from assorted public figures. It has an afterword responding to some of the reactions following its initial publication. On the other hand, this might be precisely the right time to review it. Much of what has happened since the book was published adds grist to the mill of its critics. Recent "madness" has had much more to do with the altright than with the proponents of identity politics against whom Douglas Murray turns his fire.

The first words of the book grab the reader's attention with a striking general claim. "We are going through a great crowd derangement. In public and in private, both online and off, people are behaving in ways that are increasingly irrational, feverish, herd-like and simply unpleasant." Murray almost entirely devotes his attention in the rest of the book, however, to claims that this bad behavior has infected public discourse in gender, race, and identity politics. There is, according to the blurb on the back, presumably approved by the author, a "great derangement of "woke' culture". This is nostalgically compared to a relatively recent golden age of enlightenment in which huge strides were made in addressing racism, sexism, and homophobia. Murray does not claim these problems have been "solved," but he does claim that things were on the right track until the great derangement struck. He is particularly concerned with de-platforming, online piling-on, and hypersensitive but nonetheless vicious attacks on dissenters from what he sees as the new "woke" orthodoxy.

The Madness of Crowds, therefore, is in practice a litany of complaints about what Murray paints as intolerant and

Michael Laver

michael.laver@nyu.edu

1 New York University, New York City, NY, USA vindictive attacks on old-school liberals by proponents of various strands of identity politics. Viewed as an historical document, The Madness of Crowds is a push-back (sometimes hurt, sometimes simply cantankerous) by these old-school liberals against a "woke" movement that now sees them as part of the problem rather than part of the solution. There is a lot of talk of the new cultural "tripwires" which can unexpectedly cause the bien pensants - people accustomed to being revered as "good"- to fall flat on their faces.

It is clearly true that the Germaine Greers of this world have recently tended to come a cropper for views that once caused them to be lionized. But does this mean we should condemn those more enthusiastic proponents of identity politics who have set this process in motion? Or is it simply another of those generational cultural shifts that takes places every few decades? These cause the rising generation to reject the ancien cultural regime completely, dismissing the old intellectual aristocracy en masse and caring little for distinctions between the good and the bad among them. The late 1960s and early 1970s was the last time this happened: an era of hippies, LSD, Vietnam War protests, and the Kent State massacre. Many young people saw themselves as part of a radical counter-culture, for which everything about the older generation was at best out of date and at worst downright evil. Implacable rejection of mainstream intellectuals by a new cultural vanguard is simply what does, indeed should, happen from time to time. Many who teach in universities have long complained about the political apathy of students, relative to the good old days of the 1960s. Now that at least part of the student body is on the march again, it is naive to think their new heroes would be lions of an aging liberal establishment. Many of these lions were indeed the stars of a previous cultural revolution, so are left licking their wounds in bewilderment when now denounced as reactionaries. 
Murray supplements his description of woke culture as "deranged," rather than merely intolerant of its critics, with an account of contradictions within and between its various component parts. Perhaps the most striking of these is the conflict between the transgender movement and strands of modern feminism, but conflicts between the various "letters" of LGBTQ are also described in some detail. Again, however, this is not surprising. Think of the deep and bitter animosities between factions of the socialist left during the Cold War, for example. Talking about Irish republicanism, Brendan Behan is reputed to have said that "the first item on the agenda is the split". Divisions within any developing social movement are not only to be expected, but welcomed. As new thinking evolves and develops, active participants in the movement try out, debate, and vigorously defend sometimes extreme ideas and positions. Some "extreme" ideas are abandoned and forgotten. Others, such as gay marriage or the legalization of marijuana, move right into the mainstream. And so culture evolves, more often as a result of struggle than of polite debate. Divisions within any lively social and political movement are nothing new, therefore. They may come in handy as debating points for opponents, but do not contribute to rigorous argument and insight.

What is certainly new is the Internet. Most of the examples of intolerance with which Douglas Murray fills his book have to do with the Internet. The things he complains about are published on the Internet, researched on the Internet, organized on the Internet. But the Internet is by no means the exclusive preserve of proponents of identity politics. Talking about "the madness of crowds", how about the following? The invasion of the US Capitol building, in which several people died, by people who believe a presidential election was stolen by Satan-worshipping pedophiles. An anti-vax movement that believes the global coronavirus pandemic is a hoax, hospitals are empty, and vaccinations are being used for mind control. Not only are these alt-right movements enabled and amplified by the Internet, but they involve substantial numbers of rankand-file civilians and elected members of Congress, not just elite liberal intellectuals. Murray has almost nothing to say about this. The implication is that, while identity politics merit his attention and criticism, alt-right movements, much more dangerous and also powered by the Internet, do not. On the other side of the aisle, think of Extinction Rebellion, another internet-enabled movement with substantial public support. This excites many young people, clearly has its own sectarian infights, sometimes engages in unwise and intolerant behavior, but does not attract Murray's angry attention.

The Madness of Crowds presents a long list of complaints, each illustrated with an example. As a result, it is certainly argumentative, but does not have an underlying argument. It never really drills down on "why?" Why are modern proponents of identity politics so hostile to old-school intellectuals who see themselves as allies? Why, in universities, do the authorities give in to pressure to de-platform speakers, and even sack longstanding colleagues, from a relatively small number of people "piling on" to particular targets. Why, more generally, is there so much nastiness and intolerance on certain social media platforms? What, in Murray's own terms, is making so many people "mad"?

This is clearly a crucial question, and we very much need a rigorous argument which might suggest answers, but the Madness of Crowds does not offer one. The problem, of course, is that to write off your opponents as "mad," "bad" or "deranged" means giving up any attempt to understand them. And giving up any attempt to understand people who disagree with you means that you will lose the argument. After which your only resort is to crush your opponents-if you have the stomach for this, which of course liberal intellectuals do not. Hence their angst.

A book review is no place to develop a theory of how the Internet powers the evolution of social attitudes, but there are some things we do know about this. The most important, perhaps, relative to pre-Internet social interaction, is that people can now curate their own social networks in a much more selective way, from a vast menu of possibilities. It is not surprising that we tend to choose others who agree with us and avoid others who tell us what we are saying is rubbish. And this is such an easy thing to do on the Internet. Yet people only "know" their new social contacts by what these say online. You might "like" what network neighbors say, in Internet terms. But you might well loathe these very same people were you ever to meet them in the actual flesh. The sad thing is that the people winding each other up to a frenzy in some corner of the Internet are not a community at all, in the sense of enjoying the broad spectrum of social interactions which teach us how to get on with others. They are just an almost random collection of people linked by their sayings (not even, necessarily, their real views), however wacky, on some particular matter.

How different this is from a rambunctious political discussion with friends and acquaintances in a physical pub. (Note to non-drinkers: I'm using the pub here as a metaphor for any form of enjoyable interaction with friends and acquaintances in the actual physical world.) What attracts you to your network of actual friends and acquaintances is a broad spectrum of physical and social characteristics, not a few tweets on a particular topic. These people are liable to laugh at you when you say something stupid. Your real friends sometimes say some odd things, but they remain your friends. You cut them slack because you have come to like them, and do not viciously jump up and down on the first silly thing they say. Your network of physical friends and acquaintances is much less likely to reinforce your views on every single issue. But you still keep interacting with them, continually exposing yourself to a range of different and conflicting views. A fundamental moderating mechanism is switched off when people gravitate 
away from the physical pub into virtual Internet meeting places, and this makes collective folies of any stripe much more likely.

Such folies can have much more terrible consequences than those which preoccupy Murray. Many will die if enough people believe the anti-vax nonsense they read on the Internet. Supporters of Internet-enabled alt-right movements in the USA are armed with military assault rifles. This is clearly much worse than intolerant words causing wounded pride, and even ruined careers, for a few old-school liberals. This is a madness of crowds that kills people.

We would all like to be in a better place. Vigorous but civil debate is an excellent thing. Armed militias on the street are bad. Universities should be places where students are exposed to, and taught how to vigorously challenge, ideas they find repugnant. Metaphorically burning books is never good. Murray's solution is "forgiveness" but he does not tell us how to get there. A better answer might be "tolerance," which is more likely to develop when people have positive social interactions, or share a common purpose, with others who have widely differing opinions. We need to get people back into the pub and away from dark corners of the Internet.

Can we engineer this? Probably not. Is there any hope for the future? Probably; history is a series of punctuated equilibria. Technology will surely continue to evolve and will in the process revolutionize social interactions in ways we cannot possibly imagine. Disasters will surely happen. Paradoxically, some good may come out of these if they give people a sense of common purpose. An older generation harks back nostalgically to the good old days of the war, when "everyone was on the same side." We saw recent glimmers of this during the pandemic, with new kindnesses to strangers. Whatever else it will do, the pandemic will reset the structure of social interactions - whether for better or for worse we cannot be sure yet. When the climate disaster finally overwhelms us, however, intolerance and sectarianism will be luxuries we can no longer afford.

Publisher's Note Springer Nature remains neutral with regard to jurisdictional claims in published maps and institutional affiliations.

Michael Laver is Emeritus Professor of Politics at New York University. His most recent book is Agent-Based Models of Social Life: Fundamentals (2020: Cambridge University Press) 